\title{
An Estimation Method of Available Transfer Capabilities from Viewpoint of Power System Transient Stability under Deregulated Environment
}

\author{
Tomohiko Ichikawa Student Member (Aichi Institute of Technology,itiya@aitech.ac.jp) \\ Katsuhiro Ichiyanagi Member (Aichi Institute of Technology) \\ Reiji Watanabe Student Member (Aichi Institute of Technology) \\ Kazuto Yukita Member (Aichi Institute of Technology,yukita@aitech.ac.jp) \\ Yasuyuki Goto Member (Aichi Institute of Technology,ygoto@aitech.ac.jp) \\ Yukio Hoshino Member (Chubu Electric Power Co., Inc., Hoshino.Yukio@chuden.co.jp) \\ Nobuyuki Yamamoto Member (Chubu Electric Power Co., Inc., Yamamoto.Nobuyuki@chuden.co.jp) \\ Sigeyuki Sugimoto Member (Chubu Electric Power Co., Inc., Shgeyuki.Yamamoto@chuden.co.jp)
}

Keywords : transient stability, neural network, IEEJ WEST10 model system, ATC, estimation

To conduct the electric power transactions effectively and to operate the power system efficiently while maintaining reliability under the deregulated environment, it is required that ATC (Available Transfer Capability) should be calculated at high speed with reasonable precision. The ATC is decided based on the N-1 criteria considering the thermal capacity constraint, the transient stability constraint and the voltage constraint. In this paper, it is assumed that the transient stability constraint is the most dominant within these constraints, and we propose an estimation method of the ATC from viewpoint of transient stability by using the neural network. The available transfer capabilities Pmarg (ATC) is calculated from Viewpoint of power system transient stability after the fault occurrence. The $P$ marg is obtained by subtracting $P$ tr from $P$ trmax(MTC;Maximum Transmission Capability).

The Ptrrmax is calculated by repeating and carrying out the

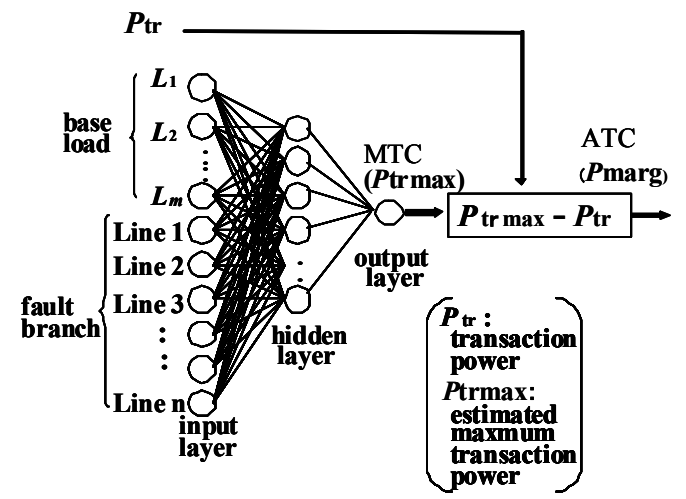

Fig. 1. Structure of neural network

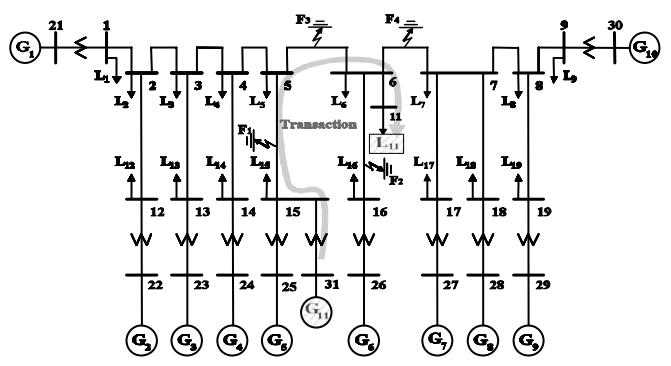

Fig. 2. IEEJ WEST10-machine system and transaction power route power flow calculation every transaction route, amount of transaction, and assumed fault branch. Therefore, very long time is needed for $P$ trmax calculation in a large-scale power system. Then the neural network which has an off-line training function is effective for calculation of Ptrmax. Ptrmax is estimated by using the neural network in an instant.

The ATC estimation system shown in Fig.1 is proposed. The estimation system has $m$ units corresponding to base load and $n$ units corresponding to assumed fault branch in the input layer. The input layer has $m+n$ units in total. The ' 1 ' is given to the fault branch and the ' 0 ' is given to other branches. The estimation system has one unit corresponding to Ptrmax. The simulations of estimation of the ATC from viewpoint of power system transient stability were carried out like the foregoing paragraph for IEEJ WEST10-machine system shown in Figure 2. The distributed generators that PPS owns are contained in G11 and the consumer that contracted a transaction with PPS is contained in L11. It is assumed that power transaction is performed from G11 to L11. The estimated results are shown in Table 1. The estimated and true ATC are almost equal. The average of absolute error estimated samples is 0.12 and ATC was estimated with sufficient accuracy. Furthermore, I examined the reduction of calculation time at learning by using the transient stability index.

Table 1. Estimated result of ATC

\begin{tabular}{|c|c|c|c|c|c|c|c|c|c|c|}
\hline \multicolumn{7}{|c|}{ Load } & \multirow{2}{*}{$\begin{array}{c}\text { Fault } \\
\text { branch }\end{array}$} & \multirow{2}{*}{$\begin{array}{c}\text { Estimated } \\
\text { MTC } \\
\text { (Ptrmax) }\end{array}$} & \multirow{2}{*}{$\begin{array}{c}\text { TRUE } \\
\text { MTC } \\
\text { (Ptrmax) } \\
\text { [p.u.] }\end{array}$} & \multirow{2}{*}{$\begin{array}{l}\text { Error } \\
\text { [p.u.] }\end{array}$} \\
\hline L2 & L3 & L4 & L5 & L6 & L7 & L8 & & & & \\
\hline \multirow{4}{*}{2.40} & \multirow{4}{*}{2.40} & \multirow{4}{*}{2.40} & \multirow{4}{*}{3.10} & \multirow{4}{*}{3.10} & \multirow{4}{*}{4.50} & \multirow{4}{*}{3.10} & 5-15 & 1.24 & 1.46 & -0.22 \\
\hline & & & & & & & $6-16$ & 1.82 & 1.86 & -0.04 \\
\hline & & & & & & & $5-6$ & 1.57 & 1.40 & 0.17 \\
\hline & & & & & & & $6-7$ & 1.16 & 1.10 & 0.06 \\
\hline \multirow{4}{*}{3.12} & \multirow{4}{*}{3.12} & \multirow{4}{*}{3.12} & \multirow{4}{*}{2.00} & \multirow{4}{*}{2.00} & \multirow{4}{*}{4.52} & \multirow{4}{*}{3.12} & $5-15$ & 1.49 & 1.74 & -0.25 \\
\hline & & & & & & & $6-16$ & 2.12 & 2.16 & -0.04 \\
\hline & & & & & & & $5-6$ & 1.97 & 2.02 & -0.05 \\
\hline & & & & & & & \begin{tabular}{|l|}
$6-7$ \\
\end{tabular} & 1.39 & 1.27 & 0.12 \\
\hline \multicolumn{10}{|c|}{$\begin{array}{l}\text { Average of estimated absolute error of } \\
\text { Maximum transaction power MTC }(\text { Ptrmax })\end{array}$} & 0.12 \\
\hline \multicolumn{10}{|c|}{$\begin{array}{c}\text { Maximum absolute error of } \\
\text { availble transaction power ATC }(\text { Pmarg })\end{array}$} & 0.25 \\
\hline
\end{tabular}




\title{
競争環境下における電力系統の過渡安定度からみた 送電可能容量の推定法の提案
}

$\begin{array}{lllll}\text { 学生員 市川 } & \text { 智彦* } & \text { 正 員 一柳 } & \text { 勝宏* } \\ \text { 学生員 渡辺 } & \text { 礼二* } & \text { 正 員 雪田 } & \text { 和人* } \\ \text { 正 員 後藤 } & \text { 泰之* } & \text { 正員 星野 } & \text { 幸雄** } \\ \text { 正 員 山本 } & \text { 信幸** } & \text { 正 員 杉本 } & \text { 重幸** }\end{array}$

\author{
An Estimation Method of Available Transfer Capabilities from Viewpoint of Power System \\ Transient Stability under Deregulated Environment \\ Tomohiko Ichikawa*, Student Member, Katsuhiro Ichiyanagi*, Member, Reiji Watanabe*, Student Member, \\ Kazuto Yukita*, Member, Yasuyuki Goto*, Member, Yukio Hoshino**, Member \\ Nobuyuki Yamamoto**, Member, Sigeyuki Sugimoto**, Member
}

\begin{abstract}
To conduct the electric power transactions effectively and to operate the power system efficiently while maintaining reliability under the deregulated environment, it is required that ATC (Available Transfer Capability) should be calculated at high speed with reasonable precision. In order to address this issue, in this paper, an Artificial Neural Network based estimation method for evaluating Maximum Transmission Capability (MTC), which is a key step but also a highly time consuming process in ATC, is proposed. It is confirmed through simulation studies that the proposed method is capable of estimating MTC (ATC) with high speed and sufficient precision. Furthermore, I examined the reduction of calculation time at learning by using the transient stability index.
\end{abstract}

キーワード : 過渡安定度, ニューラルネットワーク，IEEJ WEST10 機系統，ATC，推定

Keywords : transient stability, neural network, IEEJ WEST10 model system, ATC, estimation

\section{1. まえがき}

電力自由化の進展に伴い，信頼性と安定度を維持しつつ 多様な電力取引に対応できる電力系統の運用が求められて いる。電力自由化先進国では, 市場参加者に対し, 電力系 統の効率的利用するための「送電空き容量」の情報として, 送電可能容量(ATC:Available Transfer Capabilities) が公開さ れている(1)。このような ATC はリアルタイムの取引に対応 させるために，高速に算出することが必要となる ${ }^{(2)}$ 。

一般に, ATC は N-1 基準に基づいて, 熱容量, 過渡安定 度, 電圧安定性などを考慮して決定される(2)。しかし, 大規

* 愛知工業大学工学部電気学科

干470-0392 愛知県豊田市八草町八千草 1247

Dept. of Electrical and Electronics Engineering,

Aichi Institute of Technology

1247 Yachigusa, Yakusa-cho, Toyota 470-0392

** 中部電力 (株)

干459-8522 名古屋市緑区大高町北関山 20-1

Chubu Electric Power Co., Inc.

20-1, Kitasekiyama, Ohdaka-cho, Midori-ku, Naogya 459-8522
模系統になれば，ATC の算出時間が問題となる。ATC 算出 に関して, 種々の計算手法が提案されている(2) (9)。文献( 3 ) では, 電圧 ATCに関して, 健全時と故障発生後のノード電 圧の差から得られる指標を比較することにより, 悠しい故 障条件のスクリーニングを行っている。ATC 算定に対して, 電圧制約に基づく ATC について検討した例 ${ }^{(3)(10),(11)}$ が多く, 過渡安定度制約を考慮した検討例は少ない(5)。本論文では, 過渡安定度制約が最も支配的であると仮定することによ り, 過渡安定度からみた送電可能容量 $P_{\operatorname{marg}}$ を ATC とし, ニューラルネットワークを用いて, ATC を高速に推定する 手法を提案している。さらに, 多機系統に適用可能な過渡 安定度指標を用いることにより, 推定システムの学習デー 夕作成時間を低減できた。具体的に, 電気学会 WEST10 機モ デル系統(串形状系統)を取り上げ, PPS 事業者と託送契約を 結んだ需要家を想定することにより, 各送電線故障時にお ける送電可能余裕量の推定手法を検証している。 


\section{2. 過渡安定度からみた送電可能容量推定システ 么の構築}

$\langle 2 \cdot 1\rangle$ 送電可能容量 本論文では故障後の過渡安定 度からみた送電可能容量 $P_{\operatorname{marg}}$ (ATC) を算出する。 $P_{\operatorname{marg}}$ は最 大送電可能容量 $P_{\text {trmax }}(\mathrm{MTC}$; Maximum Transmission Capability)から現時点における送電電力 $P_{\mathrm{tr}}$ の差をとり算出した。

$$
P_{\text {marg }}=P_{\text {trmax }}-P_{\text {tr }}
$$

ここで， $P_{\text {trmax }}$ は与えられた系統のベース潮流に対して， 想定される送電電力ルート，想定故障ブランチ，送電電力 量ごとに N-1 基準に基づく故障回線除去後の過渡動摇計算 を繰り返し実施し，算出する必要がある。したがって，大 規模系統においてはかなりの時間を要すると考えられる。 そこで本報告では，ニューラルネットワークによる送電可 能余裕容量の高速推定手法を提案する。

〈2·2〉 ATC 推定システムの構築 ニューラルネット ワークを用いることにより，システムの学習時には計算時 間がかかるが学習後の運用時においては, 瞬時に推定や予 測が可能となる。本報告ではオフラインでの事前学習機能 を有し，オンライン適用時には学習結果に基づいて，送電 電力余裕量を瞬時に推定可能なニューラルネットワークシ ステムを構築した。図 1 に, 提案する送電可能容量推定の ためのニューラルネットワークを示す。

ニューラルネットワークは, 入力層には各負荷ノードの 需要量に対応するユニット $\mathrm{m}$ 個, $\mathrm{N}-1$ 基準を考慮するため の想定故障ブランチに対応するユニット $\mathrm{n}$ 個の計 $(\mathrm{m}+\mathrm{n})$ ユ ニットを設けた。故障ブランチユニットには, 故障点に 1 , その他の健全ブランチに 0 を与えた。また, 出力層には故 障線路除去時に対応する最大送電可能容量 $P_{\text {trmax }}$ を 1 ユニッ トとした。これにより推定システムの出力として送電可能 余裕容量 $P_{\text {marg }}$ の推定が可能となる。

\section{3. 送電可能容量の推定シミュレーション}

送電可能容量の推定シミュレーションに用いるモデル系

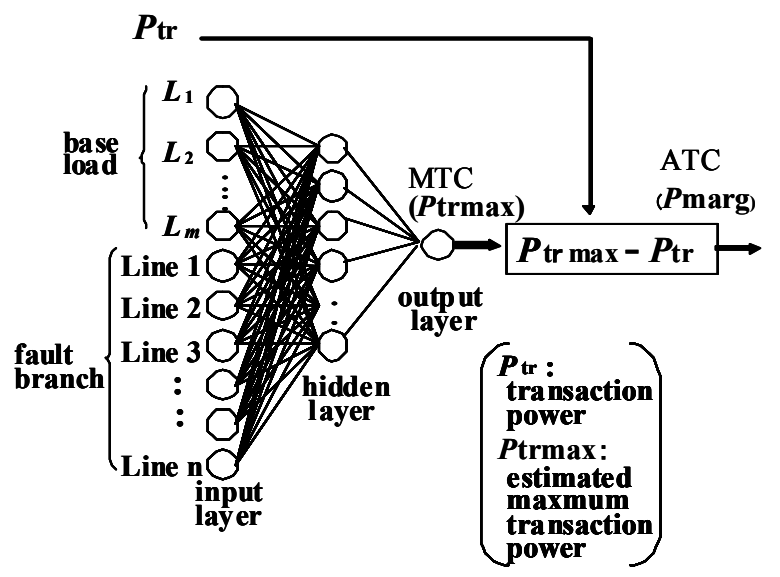

図 1 ニューラルネットワークの構造

Fig. 1. Structure of neural network
統は図 2 に示すように, 電気学会 WEST10 機系統 ${ }^{(12)}$ をべー スに, 発電機 $\mathrm{G}_{11}$ および負荷 $\mathrm{L}_{11}$ を追加した。同図において, 各ノード間はいずれも 2 回線の送電線により接続されてい るものとした。また, 発電機ノード $\mathrm{G}_{11}$ および負荷ノード $\mathrm{L}_{11}$ を追加した。 $\mathrm{G}_{11}$ として, PPS(特定規模電気事業者:Power Producer and Suppliers)が所有する分散電源を対応させ, 負荷 ノード $\mathrm{L}_{11}$ として, PPS 事業者と電力託送契約を結んだ契約 需要家を対応させた。以上により, $\mathrm{G}_{11}$ から $\mathrm{L}_{11}$ へ電力託送 が行われるものとした。

各負荷潮流状態において, 2 回線送電中 1 回線の 3 相地絡 故障 $(\mathrm{N}-1$ 基準)を想定した。託送電力が 0 の負荷状態(ベー ス潮流時)における故障線路除去後の系統について, 託送電 力量を 0.01 p.u.ずつ増加させることにより, 過渡安定度が維 持できる託送電力の最大值を求め, この值を最大送電可能 容量 $P_{\text {trmax }}$ とした。負荷の潮流状態, 故障線路および $P_{\text {trmax }}$ の関係を図 1 のニューラルネットワークに学習させた。

本論文では, 推定システムの入力ユニット数の増加によ る学習の収束性悪化を防ぐために, 先に報告した電圧安定 度からみた送電電力余裕の推定手法 ${ }^{(8)(9)}$ を用いることによ り, 厳しい故障線路のスクリーニングを実施し, 想定故障 ブランチを選定した。現時点において電圧安定度からみた 想定故障ブランチに対応するユニットは，ノード 5-15 間, 6-16 間，5-6 間，6-7 間の 4 ユニットとした。故障線路を図 2 の F1〜F4 で，それぞれ示す。

推定システムの入力層にはベース負荷 $\mathrm{L}_{2} \sim \mathrm{L}_{8}$ に対応する 7 ユニット, 想定故障ブランチに対応する 4 ユニットの計 11 ユニットを対応させ, 出力層には最大送電可能容量 $\operatorname{MTC}\left(P_{\text {trmax }}\right)$ を対応させた。中間層には学習の収束性と誤差 の検討結果から 4 ユニットとした。

学習に用いた各負荷ノードの需要量, 故障線路および最 大送電可能容量 $P_{\text {trmax }}$ の值を表 1 に示寸。故障線路は故障点 に 1 , その他の健全ブランチに 0 を与え故障のないケースも 与えた。

学習後のニューラルネットワークを用いて, 学習に用い なかった負荷状態, 故障線路を与え, $P_{\mathrm{trmax}}$ を推定し, $P_{\operatorname{marg}}$

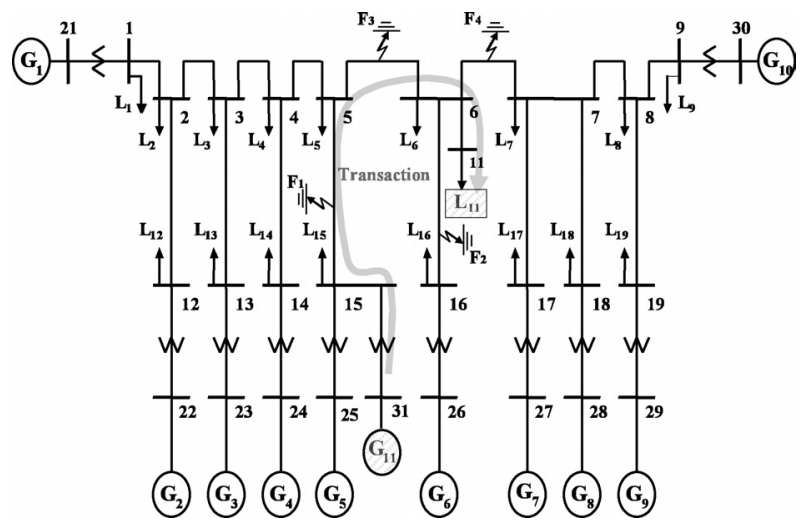

図 2 電気学会 WEST10 機系統と託送電力ルート

Fig. 2. IEEJ WEST10-machine system and transaction power route 
表 1 学習に用いたデータ

(一部抜粋)

Table 1. Data used to training of neural network (extract of used data)

\begin{tabular}{|c|c|c|c|c|c|c|c|c|c|c|c|c|c|}
\hline \multirow{2}{*}{ No. } & \multicolumn{7}{|c|}{ Base Load[p.u.] } & \multicolumn{4}{|c|}{ Fault branch } & \multirow{2}{*}{\multicolumn{2}{|c|}{$\begin{array}{c}P_{\text {tmax [p.u. }} \\
\text { [P.U.] }\end{array}$}} \\
\hline & L2 & L3 & L4 & L5 & L6 & L7 & L8 & $5-15$ & 6-16 & $5-6$ & $6-7$ & & \\
\hline 1 & 3.50 & 3.50 & 3.50 & 3.50 & 3.50 & 5.25 & 3.50 & 1 & 0 & 0 & 0 & 1.00 & \\
\hline & 3.50 & 3.50 & & & & 5.25 & & & & & & 1.42 & 4 \\
\hline 3 & 3.50 & 3.50 & 3.5 & & & 5.25 & & 0 & & & $\underline{0}$ & 1.33 & \\
\hline & 3.50 & 3.50 & 3.50 & & & 5.25 & & 0 & & & & 1.01 & \\
\hline 5 & 2.70 & 2.70 & 2.70 & 1.65 & 1.65 & 2.70 & 1.6 & 1 & & & 0 & 3.09 & \\
\hline & 2.70 & 2.70 & & & & 2.70 & & 0 & & & 0 & 3.42 & \\
\hline & 2.70 & 2.70 & 2.70 & 1.65 & 1.65 & 2.70 & 1.65 & 0 & 0 & 1 & 0 & 3.32 & 3.3 \\
\hline & 2.70 & 2.70 & 2.70 & 1.65 & 1.65 & 2.70 & 1.65 & 0 & 0 & 0 & 1 & 2.49 & 2.4 \\
\hline
\end{tabular}

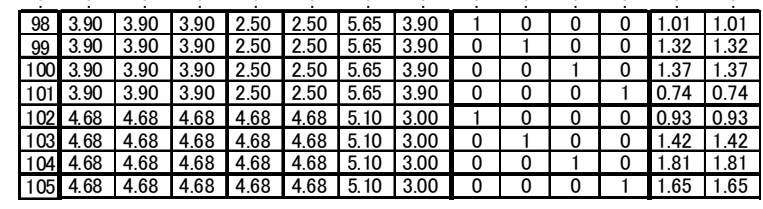

* : ここで, Fault branchの1は故障発を示し，0 は健全である ことを示す

表 2 推定に用いたデータ

Table 2. Data used to estimation of neural network

\begin{tabular}{|c|c|c|c|c|c|c|c|c|c|c|c|}
\hline \multirow{2}{*}{ No. } & \multicolumn{4}{|c|}{ Base Load[p.u.] } & \multicolumn{4}{c|}{ Fault branch } \\
\cline { 2 - 13 } & L2 & L3 & L4 & L5 & L6 & L7 & L8 & $5-15$ & $6-16$ & $5-6$ & $6-7$ \\
\hline 1 & 2.40 & 2.40 & 2.40 & 3.10 & 3.10 & 4.50 & 3.10 & 1 & 0 & 0 & 0 \\
\hline 2 & 2.40 & 2.40 & 2.40 & 3.10 & 3.10 & 4.50 & 3.10 & 0 & 1 & 0 & 0 \\
\hline 3 & 2.40 & 2.40 & 2.40 & 3.10 & 3.10 & 4.50 & 3.10 & 0 & 0 & 1 & 0 \\
\hline 4 & 2.40 & 2.40 & 2.40 & 3.10 & 3.10 & 4.50 & 3.10 & 0 & 0 & 0 & 1 \\
\hline 5 & 3.12 & 3.12 & 3.12 & 2.00 & 2.00 & 4.52 & 3.12 & 1 & 0 & 0 & 0 \\
\hline 6 & 3.12 & 3.12 & 3.12 & 2.00 & 2.00 & 4.52 & 3.12 & 0 & 1 & 0 & 0 \\
\hline 7 & 3.12 & 3.12 & 3.12 & 2.00 & 2.00 & 4.52 & 3.12 & 0 & 0 & 1 & 0 \\
\hline 8 & 3.12 & 3.12 & 3.12 & 2.00 & 2.00 & 4.52 & 3.12 & 0 & 0 & 0 & 1 \\
\hline
\end{tabular}

を算出した。推定に用いたデータを表 2 に示し, 推定結果 を表 3 に示す。同表に見られるように， $P_{\text {trmax }}$ の推定值から 得られる送電可能容量 $P_{\text {marg }}$ の值は実績值に比較的近い值 で推定できており, 送電可能容量の誤差として, 絶対值誤 差の平均が 0.12 p.u., 最大誤差は 0.25p.u.の值となった。対 象としたモデル系統による結果によれば，提案手法は有効 であることがわかる。なお, ATC 推定を算出するために,本推 定システムを用いた場合,計算時間は $2 \mathrm{msec}$ を要したのに対 し,逐次過渡動摇計算を用いた場合は $21.8 \mathrm{sec}$ を要した。

\section{4. 過渡安定度指標活用による ATC 推定法の改善}

前章までに，ニューラルネットワークを用いることによ り, ATC の高速推定手法を提案し, IEEJ WEST10 機系統を モデルとして，提案法の有効性を検証した。前述したよう に，学習後のネットワークシステムを用いることにより， オンライン運用時において, 瞬時に ATC 推定が可能となる。 しかし，オフライン時での学習データの作成とニューラル ネットワークの学習に計算時間を要する。本章では, 文献 (13)で提案されている過渡安定度指標を用いることにより, オフライン時における推定システムの学習データ作成のた めの計算時間の高速化について検討している。
表 3 推定結果

Table 3. Estimated result

\begin{tabular}{|c|c|c|c|c|c|c|c|c|c|c|}
\hline \multicolumn{7}{|c|}{ Load } & \multirow{2}{*}{$\begin{array}{l}\text { Fault } \\
\text { branch }\end{array}$} & \multirow{2}{*}{$\begin{array}{c}\text { Estimated } \\
\text { MTC } \\
\text { (Ptrmax) } \\
\text { [p.u.] }\end{array}$} & \multirow{2}{*}{$\begin{array}{c}\text { TRUE } \\
\text { MTC } \\
\text { (Ptrmax) } \\
\text { [p.u.] }\end{array}$} & \multirow{2}{*}{$\begin{array}{l}\text { Error } \\
\text { [p.u. }]\end{array}$} \\
\hline L2 & L3 & L4 & L5 & L6 & L7 & L8 & & & & \\
\hline \multirow{4}{*}{2.40} & \multirow{4}{*}{2.40} & \multirow{4}{*}{2.40} & \multirow{4}{*}{3.10} & \multirow{4}{*}{3.10} & \multirow{4}{*}{4.50} & \multirow{4}{*}{3.10} & $5-15$ & 1.24 & 1.46 & -0.22 \\
\hline & & & & & & & $6-16$ & 1.82 & 1.86 & -0.04 \\
\hline & & & & & & & $5-6$ & 1.57 & 1.40 & 0.17 \\
\hline & & & & & & & $6-7$ & 1.16 & 1.10 & 0.06 \\
\hline \multirow{4}{*}{3.12} & \multirow{4}{*}{3.12} & \multirow{4}{*}{3.12} & \multirow{4}{*}{2.00} & \multirow{4}{*}{2.00} & \multirow{4}{*}{4.52} & \multirow{4}{*}{3.12} & $5-15$ & 1.49 & 1.74 & -0.25 \\
\hline & & & & & & & $6-16$ & 2.12 & 2.16 & -0.04 \\
\hline & & & & & & & $5-6$ & 1.97 & 2.02 & -0.05 \\
\hline & & & & & & & $6-7$ & 1.39 & 1.27 & 0.12 \\
\hline \multicolumn{10}{|c|}{$\begin{array}{l}\text { Average of estimated absolute error of } \\
\text { Maximum transaction power MTC (Ptrmax) }\end{array}$} & 0.12 \\
\hline \multicolumn{10}{|c|}{ 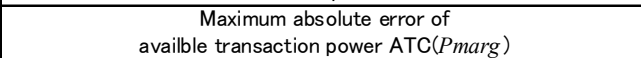 } & 0.25 \\
\hline
\end{tabular}

〈4·1〉過渡安定度指標故障が発生した場合, 系統 全体の発電機について, 安定な発電機群 A と不安定な発電 機群 S とに分ける。各発電機群の動摇を位相中心の考え方 で表すと, 2 系統のモデルに縮約される。等価 1 機無限大母 線系統に簡略化する。縮約後の系統における安定平衡点を $\theta a$ ，不安定平衡点を $\theta u$ とする。

$$
\phi(t)=\delta(t)-\theta_{a}(t)
$$

さらに,位置エネルギーを $P E$, 運動エネルギーを $K E$ とし

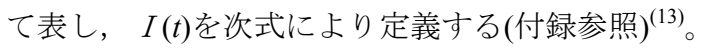

$$
I(t)=\frac{P E\left(\delta_{u}\right)-P E(\phi(t))-K E(\dot{\phi}(t))}{P E\left(\theta_{u}\right)-P E\left(\theta_{\mathrm{a}}\right)}
$$

故障除去後における $I(t)$ の值のうち最小值を $I_{\min }$ とする。 $I_{\min }$ は $I_{\min }>0$ で安定, $I_{\min }<0$ で不安定を意味する。

〈4·2〉過渡安定度評価のシミュレーション 過渡安 定度指標の評価に用いるモデル系統として, IEEJ WEST10 機系統 ${ }^{(12)}$ を用い, 故障線路 2-12 および故障時間 $0.21 \mathrm{~s}$ とし て, 各発電機位相 $\delta_{\mathrm{k}}(t)$ および $I(t)$ の計算結果を図 3 および 図 4 に各々示寸。図 3 から, 故障後の各発電機は大きく動 摇するものの, 安定を維持できていることが分かる。図 4 では $I(t)$ の值は故障除去の直後, 減少するものの最小值 $I_{\min }$ $=-0.01$, 以後, 正の值を呈している。

故障点, 故障持続時間を変化させて, 同様のシミュレー ションを実施し, 系統の安定性と $I_{\min }$ との関係を調べた。そ の結果を○(安定), ×(不安定)にて表 4 にまとめた。同表に は,故障線路 4-14,同 6-16 の場合の結果も併記した。

いずれも, $I_{\min }>0$ で安定, $I_{\min }<0$ で不安定となることが分 かる。同表には過渡動摇計算の中で指標 $I(t)$ が負值となる時 刻(Judgemmment time of unstability で,単位を s で示す)も併記 してある。

結果をみると, 評価指標 I min が負の場合, 系統は不安定 となる。他の故障線路の場合についても, 同様の傾向が見 られた。与えられた系統状態における安定, 不安定を判別す る場合,過渡動摇計算において, $I(t)<0$ の時点で系統は不安 定と判定される。託送電力を逐次変化させて, 安定, 不安定状 況から最大送電可能容量 $P_{\text {trmax }}$ を高速に算出する際, $I(t)<0$ の時点で不安定が確定され, 以後の動摇計算が不要になり, 


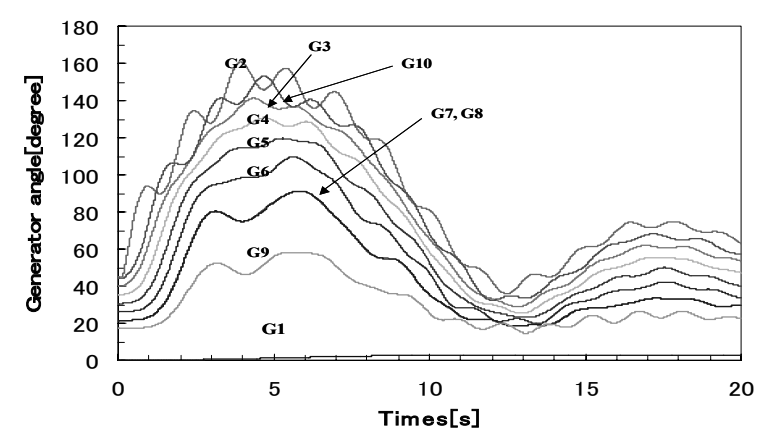

図 3 発電機位相動摇 (故障線路 2-12,故障時間 $0.21 \mathrm{~s}$, 臨界的安定)

Fig. 3. Swing curves of generator angle (fault line: $2-12$, fault duration:0.21s, stability : critical)

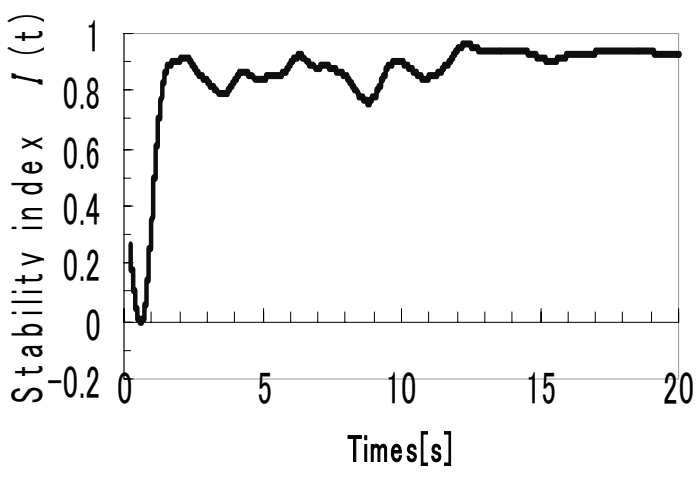

図 4 過渡安定度指標 $I(t)$

(故障線路 2-12, 故障時間 $0.21 \mathrm{~s}$, 臨界的安定, $I_{\min }=-0.01$ )

Fig. 4. Transient stability index $I(t)$ (fault line : 2-12, fault duration : $0.21 \mathrm{~s}$, stability:critical, $I_{\min }=-0.01$ )

計算時間の短縮が図れる。

〈4·3〉 $I_{\min }$ を用いた学習データ作成 前節で述べた ように, 評価指標 $I_{\min }$ が負の場合, 系統は不安定となること がわかる。推定システムの学習データは与えられた潮流状 態における故障後の系統が安定かどうかの結果から決定さ れる。したがって, 学習データは種々の潮流状態を与える ことにより過渡計算を行い, 故障後の評価指標 $I(t)$ が負の值 を示した時点で系統は不安定として判定され，計算を終了 とする。不安定と判定された場合, それ以後の動摇計算が 不要となり, 計算時間の短縮が図れる。

図 5 に過渡安定度評価指標と託送電力の関係を表す概念 図を示す。託送電力は系統の最大送電可能容量 $P_{\text {trmax }}$ (MTC; Maximum Transmission Capability) の範囲内で指標 $I_{\min }$ は正值 を示し， $P_{\mathrm{trmax}}$ を超えると $I_{\min }$ は負值を与えることを示して いる。したがって, 故障後の安定判別として, $I_{\min }$ の正負值 を参照することにより， $P_{\text {trmax }}$ を求めることができる。この $P_{\text {trmax }}$ を用いて, 送電可能容量 $P_{\text {marg }}($ ATC) を算出する。なお, $P_{\text {marg }}$ は, 最大送電可能容量 $P_{\text {trmax }}$ から現時点における送電電 力 $P_{\mathrm{tr}}$ の差をとり算出した。ここで, $P_{\mathrm{trmax}}$ は想定される送電 電力ルート, 想定故障ブランチ, 送電電力量ごとに潮流計 算を繰り返し実施し，算出する必要がある。
表 4 安定度指標 $I_{\min }$

Table 4. Stability index $I_{\min }$

\begin{tabular}{|c|c|c|c|c|c|c|c|}
\hline \multirow{4}{*}{$\begin{array}{c}\text { Fault line } \\
2-12\end{array}$} & $\begin{array}{c}\text { Fault } \\
\text { duration } \\
\text { (sec) }\end{array}$ & 0.23 & 0.22 & 0.21 & 0.2 & 0.19 & 0.18 \\
\hline & $\begin{array}{l}\text { Index } \\
(I \min ) \\
\end{array}$ & -3.05 & -3.13 & -0.01 & 0.13 & 0.38 & 0.48 \\
\hline & Stability & $x$ & $x$ & $\mathrm{O}^{*}$ & 0 & 0 & 0 \\
\hline & $\begin{array}{c}\text { Judgment } \\
\text { time of } \\
\text { unstability } \\
\text { (sec) }\end{array}$ & 0.05 & 0.05 & 0.51 & --- & --- & -- \\
\hline \multirow{4}{*}{$\begin{array}{c}\text { Fault line } \\
4-14\end{array}$} & $\begin{array}{c}\text { Fault } \\
\text { duration } \\
\text { (sec) }\end{array}$ & 0.26 & 0.25 & 0.24 & 0.23 & 0.22 & 0.21 \\
\hline & $\begin{array}{l}\text { Index } \\
(I \min ) \\
\end{array}$ & -0.66 & -0.51 & -0.21 & -0.08 & 0.04 & 0.16 \\
\hline & Stability & $x$ & $x$ & $x$ & $\mathrm{O}^{*}$ & 0 & 0 \\
\hline & $\begin{array}{c}\text { Judgment } \\
\text { time of } \\
\text { unstability } \\
\text { (sec) }\end{array}$ & 0.0167 & 0.0167 & 0.017 & -- & -- & --- \\
\hline \multirow{4}{*}{$\begin{array}{c}\text { Fault line } \\
6-16\end{array}$} & $\begin{array}{c}\text { Fault } \\
\text { duration } \\
(\mathrm{sec})\end{array}$ & 0.28 & 0.27 & 0.26 & 0.25 & 0.24 & 0.23 \\
\hline & $\begin{array}{l}\text { Index } \\
(I \min ) \\
\end{array}$ & -81.60 & -14.10 & 0.51 & 0.55 & 0.19 & 0.06 \\
\hline & Stability & $x$ & $x$ & 0 & 0 & 0 & 0 \\
\hline & \begin{tabular}{|} 
Judgment \\
time of \\
unstability \\
(sec)
\end{tabular} & 0.0167 & 0.0167 & -- & --- & -- & --- \\
\hline
\end{tabular}

$\bigcirc^{*}$ : critical satable state

Judgment time of unstability : time from fault clearance

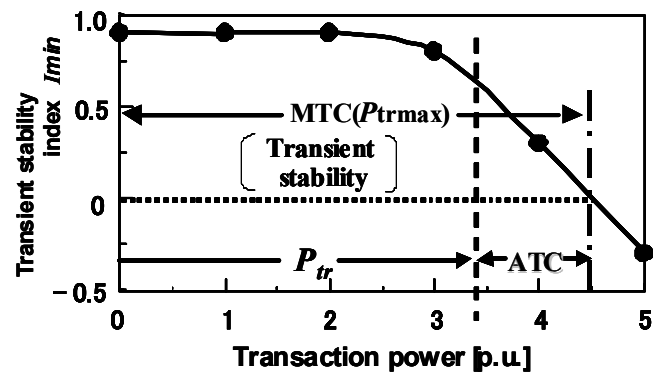

図 5 安定度評価指標 $I_{\min }$ と託送電力

Fig. 5. Stability index $I_{\min }$ versus transaction power

想定される託送ルートに対して, 安定限界を与える託送 電力 $P_{\mathrm{trmax}}$ を求めた。計算としては, 託送電力 $P_{\mathrm{tr}}$ に大きい 值を与え, 不安定な状態から順次, $P_{\mathrm{tr}}$ を減少させていくこ とにより, 安定な状態 $\left(I(t)>0 ; t<t_{\mathrm{fin}}\right)$ となる $P_{\mathrm{tr}}$ を $P_{\mathrm{trmax}}$ とし た。ここで, 不安定な状態は $I(t)<0$ となったことによりで 判定し, 一連の過渡動摇計算は終了した。これにより, 計 算時間は大幅に短縮できる。 $I_{\min }$ を用いた学習データ作成結 果の例を表 5 に示す。同表の右端欄に, $I(t)<0$ の条件で不安 定と評価することにより, 安定度限界 $P_{\text {trmax }}$ を算出し, ケー ス 1 とした。他方, 各発電機 $\delta(t)$ の動摇状況 $\left(\delta(t)>180^{\circ}\right)$ から, 不安定と判断し, $P_{\text {trmax }}$ を算出し, ケース 2 とした。 両ケースとも，近い值を示していることがわかる。また， ケース 1 はケース 2 に比べて, 学習データ作成のための計 算時間は数倍速くできた。 
表 $5 I_{\min }$ を用いて作成した学習データ

Table 5. Trainning data by using index $I(t)<0$

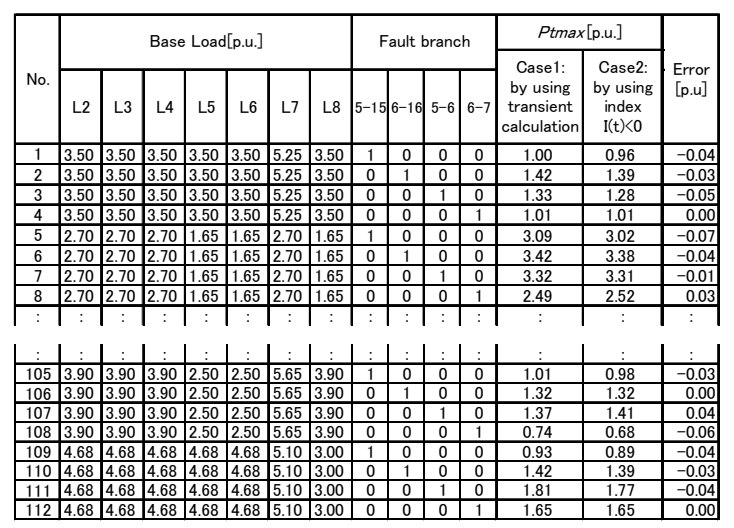

\section{5. あとがき}

ATC は系統の有する送電能力の上限を数值化したもので あり，(1)熱容量制約，(2)安定度制約，(3)電圧制約を考慮し て決定される。本論文では，与えられた系統の特性から， 過渡安定度制約が支配的であるとして, 送電可能容量(ATC) の高速推定法を提案した。具体的に, ニューラルネットワー クを用いることにより ATC 推定システムを構築し, 10 機串 形系統に対して, PPS 事業者と託送契約を結んだ需要家が含 まれるものとして検討した。その結果, 学習後の推定シス テムを用いることにより, 送電可能容量が比較的精度良く, 高速に推定できることを確認した。また, 学習データ作成 の際, $\mathrm{N}-1$ 基準に基づく故障除去後の系統の安定度性を表 す指標 $I(t)$ の導入を試みた。その結果, $I(t)$ の最小值 $I_{\min }$ の值 が負の場合に不安定となることを利用することにより，学 習データ作成に要する計算時間が短縮できた。なお,用いた ニューラルネットワークは一般的に用いられる 3 層階層型 を用いているが,その構成やネットワークの学習法について 今後,改善する必要がある。

また,線路故障の他に,電源脱落の有無情報を推定システ ムの入力情報として追加することにより,同様の検討が可能 と考えられる。電源脱落を含む想定故障については今後の 検討課題としたい。さらに, 実際の大規模系統を対象とし, 実系統での運用を視野に入れた ATC 推定システムとして改 良を図るとともに，電圧安定性からみた ATC 推定法と結合 させた ATC 推定法について検討を進める予定である。

(平成 18 年 3 月 28 日受付, 平成 19 年 2 月 2 日再受付)

\section{文献}

（1）競争環境下における電力品質調查専門委員会: 競争環境下における 電力品質」, 電気学会技術報告, 第 925 号 (2003)

(2) “Available Transfer Capability Definition and Determination",North American Electric Reliability Council, June (1996)

(3) M. Nagata, A. Takehara, and K. Tanaka : "Development of ATC assessment method -A fast assessment method of ATC with thermal and voltage constrains-", Komae Research laboratory Rep. No.T01020 (2002-4) (in Japanese)
永田真幸・竹原有紗・田中和幸 : 「送電可能容量 (ATC) の評価手法 の開発一熱容量および電圧 ATC の高速計算手法一」, 電力中央研究 所報告 T01020 (2002-4)

(4) H. Okamoto, R. Tanabe, Y. Tada, and Y. Sekine : "A Method for Voltage Stability Constrained Optional Power Flow(VSCOPF)", T. IEE Japan, Vol.121-B, No.12, pp.1670-1680 (2001-12) (in Japanese) 岡本 浩 - 田边隆也・多田泰之・関根泰次: 「電圧安定度制約を考慮 した最適潮流計算手法」, 電学論 B, 121, 12, pp.1670-1680 (2001-12)

(5) Y. Yamada, M. Nagata, and K. Tanaka : "Contingency Screening Method for ATC Assesment with Transient Constrains", Proceedings of National Convention. IEE of Japan, 6-001 (2002-3) (in Japanese)

山田義徳・永田真幸・田中和幸 : 「過渡安定度 ATC 評価のための想 定事故スクリーニング手法」, 平 14 電学全大, 6-001 (2002-3)

(6) Y. Hayashi, J. Matsuki, and T. Ikeda : "Computation Method for Simultaneous Transer Capability Considering Wheeled Power by PPS", $T$. IEE Japan, Vol.122-B, No.12, pp.1366-1375 (2002-12) (in Japanese) 林 泰弘・松木純也・池田孝之: 「PPS の系統参入に対する同時送電 可能容量（STC）の計算手法」, 電学論 B, 122, 12, pp.1366-1375 (2002-12)

(7) M. Nagata, M. Takemura, T. Okada, and K. Tanaka : "Development of ATC Assessment Syatem", Proceedings of the Thirteenth Annual Conference of Power \& Energy Society. IEE of Japan(Volume A), No.143 (2002-8) (in Japanese)

永田真幸・竹村昌彦・岡田俊之・田中和幸：「ATC 自動算定システ ムの開発」, 電気学会電力・エネルギー部門大会論文集 (分冊 $\mathrm{A}$ ), No.143 (2002-8)

(8) K. Ichiyanagi, S. Washizu, T. Ichikawa, K. Yukita, Y. Goto, N. Yamamoto, Y. Hoshino, and S. Sugimoto : "Estimation of ATC from Viewpoint of Voltage Stability in Multi-machine Power System", Wseas Transactions on Power Systems, Issue 2. Vol.1, pp.331-337, February (2006) ISSN:1790-5060

(9) H. Yamada, K. Yukita, Y. Goto, K. Ichiyanagi, Y. Tabata, and S. Ogawa : "Estimation of ATC in View of Voltage Stability in Multi-machine Power System", The Papers of Joint Technical Meeting on Power Engineering and Power System Engineering, IEE Japan PE-03-127, PSE-03-138, pp.39-43 (2003-9) (in Japanese)

山田 浩・雪田和人・後藤泰之一一柳勝宏・田端康人・小川重明:「多 機電力系統の電圧安定度からみた送電電力余裕の推定」, 電学電力技 術・電力系統技術合同研資, PE-03-127, PSE-03-138, pp.39-43 (2005-9)

(10) Y. Kamemura and S. Iwamoto : "A Study on voltage stability ATC in the Deregulated Environment" The Papers of Joint Technical Meeting on Power Engineering and Power System Engineering, IEE Japan PE-05-140, PSE-05-147, pp.1-6 (2005-9) (in Japanese)

亀村祐介・岩本伸一: 「電力自由化環境下における電圧 ATC に関す る考察」, 電学電力技術 - 電力系統技術合同研資, PE-05-140, PSE-05-147, pp.1-6 (2005-9)

(11) N. Yorino, Y. Zoka, K. Kawano, K. Okagawa, and H. Q. Li : "Proposal of Fast Computation for Voltage and Thermal Magnitude ATC", The Papers of Joint Technical Meeting on Power Engineering and Power System Engineering, IEE Japan PE-05-141, PSE-05-148, pp.7-11 (2005-9) (in Japanese)

餘利野直人・造賀芳文・川野晃紀・岡川康二・李華強：「熱容量・電 圧 ATC の高速計算法の提案」, 電学電力技術 - 電力系統技術合同研 資，PE-05-141, PSE-05-148, pp.7-11 (2005-9)

(12) 電力系統モデル標準化調査専門委員会 : 「電力系統の標準モデル」, 電気学会技術報告第 754 号 (1999)

(13) A. Rahimi and K. N. Stanton: "Dynamic Aggregation and the Calculation of Transient Stabiity Indices", IEEE Trans. PAS-91, No.1, pp.118-122 (1972)

\section{付 録}

\section{系統縮約とエネルギ一関数}

多機系統の全発電機について, 安定な発電機群 A と不安 定な発電機群 S とに分ける。各発電機群の動摇を位相中心 の考え方で表すと, 次式の 2 系統のモデルに縮約される。 


$$
\begin{aligned}
& M_{a} \frac{d^{2} \delta_{a}}{d t^{2}}=\sum_{k \in A}\left(P_{m k}-P_{e k}\right) \\
& M_{s} \frac{d^{2} \delta_{s}}{d t^{2}}=\sum_{l \in S}\left(P_{m l}-P_{e l}\right)
\end{aligned}
$$$$
\delta_{a}=\frac{\sum_{i \in A} M_{i} \delta_{i}}{\sum_{i \in A} M_{i}}
$$$$
\delta_{s}=\frac{\sum_{i \in S} M_{i} \delta_{i}}{\sum_{i \in S} M_{i}}
$$

さらに，集合 $\mathrm{A}$ における集合 $\mathrm{S}$ からの相対的な位相差を $\delta$ とすると, 以下の 1 機無限大母線系で表される縮約モデ ルが得られる。

$$
\begin{aligned}
& M \frac{d^{2} \delta}{d t^{2}}=P_{m}-\left\{P_{c}+P_{e m} \sin (\delta-v)\right\} \\
& \delta=\delta_{s}-\delta_{a} \\
& v=\tan ^{-1}\left(\frac{M_{T}}{M_{a}-M_{s}} \tan \delta\right)-\frac{\pi}{2}
\end{aligned}
$$

ここで, 縮約後の系統における安定平衡点を $\theta a$, 不安定平 衡点を $\theta u$ とする。発電機の位相 $\delta(t)$ と $\theta a$ の差 $\phi k(t)$ を ある時刻における運転点とする。

$$
\phi(t)=\delta(t)-\theta
$$

さらに，位置エネルギーを $P E ，$ 運動エネルギーを $K E$ と して表し，I $t$ )を次式により定義する ${ }^{(13)}$ 。位置エネルギー と運動エネルギーの関係を示す概念図を付図 1 に示す。

$$
I(t)=\frac{P E\left(\delta_{u}\right)-P E(\phi(t))-K E(\dot{\psi}(t))}{P E\left(\theta_{u}\right)-P E\left(\theta_{\mathrm{a}}\right)}
$$

故障除去後における $I(t)$ の值のうち最小值を Imin とす る。 I min は I $\min >0$ で安定， I $\min <0$ で不安定を意味する。

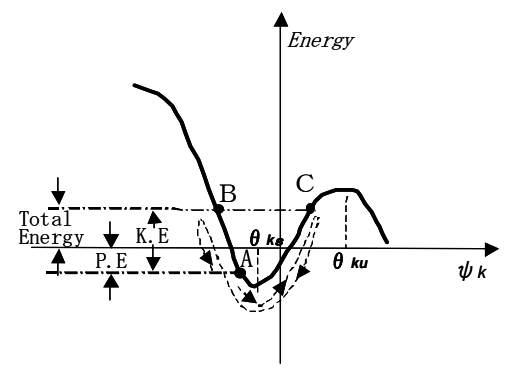

(a) stable conditions

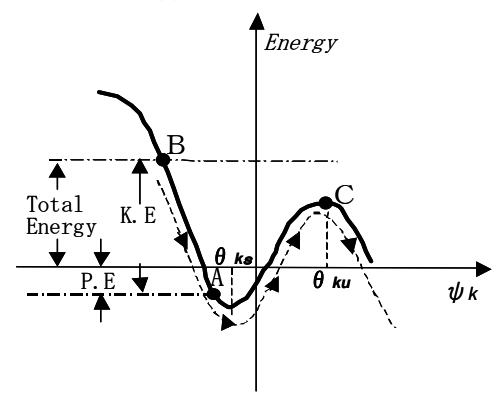

(b) unstable conditions

付図 1 縮約系統の運動エネルギーと位置エネルギー Appendix fig.1 Kinetic and potential energy of simplified power system

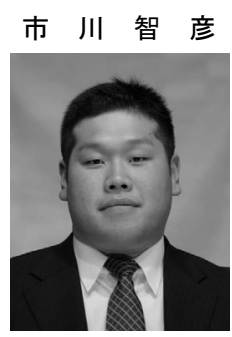

（学生員） 1981 年生。2004 年 3 月愛知工業大 学電気工学科卒業。2006 年 3 月同大学大学院工 学研究科修士課程電気電子工学専攻修了。現 在, 三重県立四日市工業高等学校講師。主とし て電力系統の安定化に関する研究に従事。

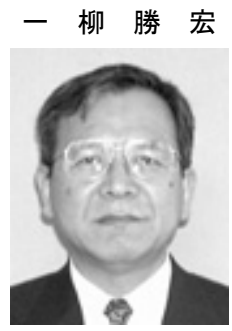

（正員） 1945 年生。1970 年 3 月愛知工業大学 大学院工学研究科修士課程修了。同年同大学助 手。その後,同講師，同助教授を経て，1993 年 教授, 現在に至る。工学博士。主として電力系 統の安定度および自然エネルギーの有効利用 に関する研究に従事。電気設備学会,日本太陽工 ネルギー学会,IEEE など各会員。

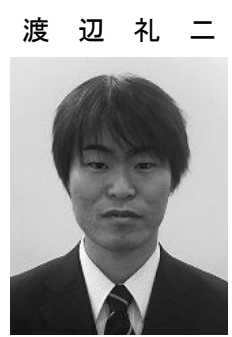

（学生員） 1984 年生。 2006 年 3 月愛知工業大 学電気工学科卒業。同年 4 月名古屋大学大学院 工学研究科修士課程（電子情報システム専攻） 入学, 現在に至る。主として電力システムの解 析，安定化に関する研究に従事。

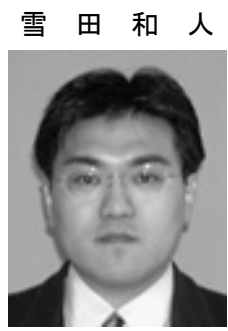

（正員） 1967 年生。1997 年 3 月東海大学大学 院工学研究科博士課程修了。同年愛知工業大学 助手。1 998 年同講師。2003 年同助教授, 現在 に至る。博士(工学)。主として電力系統の運用 · 制御に関する研究に従事。電気設備学会, 日本 風力エネルギー協会, IEEE など各会員。

後 藤 泰 之

(正員) 1958 年生。1 985 年 3 月東海大学大学 院工学研究科博士課程満了。同年同大学助手。 1988 年同講師。1991 年名古屋大学工学部講師。 1994 年愛知工業大学助教授。2000 年同大学教 授。2003 年中国東南大学客座教授。2004 年愛 知工業大学学長, 現在に至る。工学博士。主とし て電力系統の運用・制御に関する研究に従事。 IEEE など各会員。

星 野 幸 雄

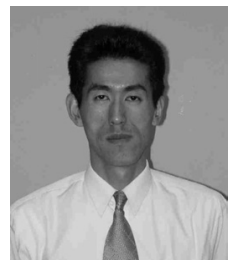

（正員） 1971 年生。1994 年 3 月東洋大学工学 部電気工学科卒業。同年 4 月中部電力(株)入社。 現在, 同社電力技術研究所に勤務。主として電 力系統の解析技術および制御機器に関する研 究に従事。 
山 本 信 幸 (正員) 1958 年生。1983 年 3 月中部工業大学

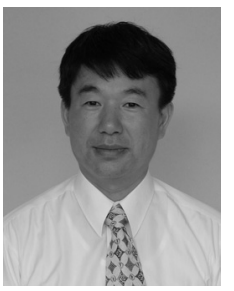

大学院工学研究科修士課程電気工学専攻修了。

同年 4 月中部電力(株)入社。現在，同社電力技

術研究所に勤務。主として電力系統の解析モデ

ルおよび瞬低補償機器に関する研究に従事。

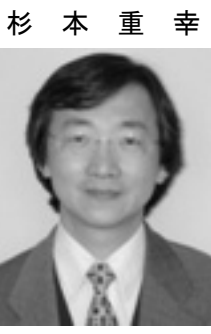

（正員） 1958 年生。1983 年 3 月岐阜大学大学 院工学研究科修士課程電気工学専攻修了。同年 4 月三菱電機(株)入社。1991 年 9 月中部電力(株) 入社。現在, 同社電力技術研究所に勤務。主と して電力機器・電力系統へのパワエレ技術の適 用および瞬低補償機器に関する研究に従事。博 士(工学)。1998 年電気学会電気学術振興賞論文 賞, 2005 年同進歩賞受賞。 